\title{
Gallbladder Cancer pN1 TNM Finding v6
}

National Cancer Institute

\section{Source}

National Cancer Institute. Gallibladder Cancer pN1 TNM Finding v6. NCI Thesaurus. Code C67181.

Gallbladder cancer with regional lymph node metastasis. (from AJCC 6th Ed.) 